\title{
PENERAPAN EDINBURGH POST-PARTUM DEPRESSION SCALE SEBAGAI ALAT DETEKSI RISIKO DEPRESI NIFAS PADA PRIMIPARADAN MULTIPARA
}

\author{
Soep* \\ Jurusan Keperawatan Poltekes Kemenkes Medan, Sumatera Barat 20136, Indonesia \\ *Email:so3p_221270@yahoo.com
}

\begin{abstract}
Abstrak
Ibu menggambarkan depresi nifas sebagai mimpi buruk dengan kecemasan yang tidak terkontrol, rasa bersalah, dan pikiran obsesif. Kontemplasi wanita tersebut bukan hanya membahayakan dirinya sendiri tapi juga bayi mereka. Ibu merasa kesepian dan kualitas hidup menurun, yang berpengaruh terhadap kurangnya emosi positif. Hampir $50 \%$ kasus depresi nifas tidak terdeteksi. Edinburgh Postnatal Depression Scale (EPDS) adalah alat yang dirancang khusus untuk menyaring penyimpangan suasana hati. Tujuan dari penelitian ini adalah mengevaluasi risiko depresi nifas pada primipara dan multipara menggunakan EPDS. Penelitian survei ini menggunakan pendekatan kuantitatif sebanyak 50 pasien terpilih dengan metode purposive sampling. Hasil penelitian independent $t$-test menunjukkan perbedaan risiko yang signifikan depresi nifas pada wanita primipara dan multipara ( $p=0,000 ; \alpha=0,05)$. Disarankan untuk menerapkan skala Edinburgh sebagai alat deteksi depresi nifas pada ibu primipara dan multipara mengingat bahwa depresi nifas kadang terjadi tanpa diketahui dulu sebelumnya.
\end{abstract}

Kata kunci: depresi nifas, Edinburgh Post-partum Depression Scale (EPDS)

\begin{abstract}
Mothers describe postpartum depression as a living nightmare filled with uncontrollable anxiety, consuming guilt, and obsessive thinking. These conditions do not only harm themselves but also their infants. Mothers are enveloped in loneliness and the quality of their lives is further compromised by a lack of all positive emotions. Up to $50 \%$ of all cases of postpartum depression go undetected. The Edinburgh Postnatal Depression Scale (EPDS) has been the only instrument available that was specifically designed to screen for this mood disorder. The aim of this study is to evaluate risk of postpartum depression differences of primiparous and multiparous mother by using EPDS. This study utilized survey with quantitative approach. Fourty patients were chosen with purposive sampling method. The result of the study especially the independent $t$-test shows that there was significant differences of postpartum depression risk of primiparous and multiparous women ( $p=0.000 ; \alpha=$ 0.05). It is recommended to apply the scale of Edinburgh as tools detection of postpartum depression in mothers primiparous and multiparous considering that postpartum depression often occurs without any known beforehand.
\end{abstract}

Keywords: post partum depression, Edinburgh Post-partum Depression Scale (EPDS)

\section{Pendahuluan}

Tugas perkembangan seorang wanita secara kodrati adalah hamil dan melahirkan. Namun demikian, peristiwa kelahiran dan persalinan dapat menimbulkan berbagai gangguan emosional pada periode setelah melahirkan (periode nifas). Salah satu variasi gangguan emosional pada wanita nifas periode nifas adalah depresi nifas. Kejadian depresi nifas ini banyak dialami terutama oleh para wanita yang baru melahirkan pertama kali (primipara mother). Penelitian oleh O'Hara dan Swain (1996), melaporkan sekitar $13 \%$ wanita melahirkan anak pertama mengalami depresi nifas pada periode tahun pertama nifas.
Penelitian yang dilakukan oleh Tammentie, Tarkka, Astedt-Ukrki, dan Paavilainen (2002), melaporkan bahwa depresinifas berkisar 10-15\% diakui sebagai problem kesehatan wanita di dunia. Hasil dari berbagai penelitian dalam sepuluh tahun terakhir melaporkan 10-15\% dari para wanita setelah melahirkan mengalami depresi nifas (Beck, et al, 1992; Campbell \& Cohn, 1991). Depresi nifas dapat mengakibatkan terjadinya gangguan psikologis jangka pendek dan jangka panjang, tidak saja pada wanita penderita tapi juga pada anak dan anggota keluarga lainnya (Armstrong, Fraser, Dadds, \& Morris, 2000).

Selain itu juga dapat terjadi gangguan hubungan tali kasih ibu dan anak, kurangnya perhatian ibu dalam 
merawat, mengasuh serta membesarkan anaknya, kesulitan anak dalam menjalin hubungan sosial dengan lingkungan dan teman sebaya serta konflik perkawinan (Kustjens \& Wolke, 2001). Akibat lain dilaporkan oleh Cooper dan Murray (1998) bahwa anak-anak yang berusia lebih dari 1 tahun dari ibu yang mengalami depresi nifas mempunyai problem tingkah laku dan memiliki kemampuan kognitif yang kurang dibanding anak-anak dari ibu yang tidak mengalami depresi nifas.

Hasil penelitian longitudinal yang dilakukan oleh Sharp et al., (1995) menemukan bahwa anak lakilaki berusia 4 tahun dari ibu yang mengalami depresi nifas secara signifikan memiliki hasil tes kemampuan intelektual yang lebih rendah dibandingkan temanteman sebaya mereka. Di Indonesia, wanita dengan depresi nifas belum dilaporkan secara pasti insidensinya. Biasanya penderita baru akan dikenali bila kondisinya sudah mengalami depresi berat (postpartum psychosis). Berbagai studi depresi nifas telah diajukan untuk menemukan beberapa kemungkinan penyebab gangguan emosional tersebut, namun depresi nifas masih merupakan misteri yang sulit dipahami.

Wanita penderita di masyarakat pada umumnya tidak menampakkan gejala depresi karena mereka takut dan malu mendapat anggapan bahwa mereka tidak mampu menjalankan peran sebagai seorang ibu. Kebanyakan penderita yang mencari pertolongan datang ke pelayanan kesehatan, hanya sedikit mengungkapkan perasaan depresi mereka dan hanya melaporkan gejala-gejala fisik yang dirasakan mengganggu. Peran perawat di komunitas dan keterlibatan praktisi kesehatan secara profesional sangat diperlukan untuk melakukan deteksi dan pencegahan depresi nifas di masyarakat. Penelitian ini bertujuan untuk menganalisis perbedaan terjadinya risiko depresi nifas antara primipara dan multipara berdasarkan penerapan Skala Edinburgh.

\section{Metode}

Penelitian ini adalah bersifat survei dengan pendekatan kuantitatif. Lokasi penelitian dilakukan di Rumah Sakit
Umum. Penelitian ini dilaksanakan selama 5 bulan yang terbagi dalam tiga tahap yaitu tahap persiapan, tahap pelaksanaan dan tahap penyusunan laporan hasil penelitian. Populasi penelitian ini adalah ibu nifas primipara maupun multipara yang ada di ruang rawat inap bersalin Rumah Sakit Umum.

Pemilihan sampel dengan cara purposive sampling. Sampel penelitian sebanyak 50 pasien dengan pembagian $25 \mathrm{ibu}$ primipara dan $25 \mathrm{ibu}$ dengan multipara. Kriteria inklusi pasien tidak mempunyai riwayat depresi post partum sebelumnya, tidak mengalami stres selama kehamilannya dan postpartum mother hari ke tujuh atau lebih.

Instrumen penelitian yang digunakan adalah Skala Edinburgh yang terdiri dari 10 item pernyataan dengan 4 pilihan jawaban dimana masing-masing jawaban mempunyai skor 0-3. Cara penyebaran dan pengisian kuisioner Skala Edinburgh dengan memberi tanda silang (X) pada jawaban yang dipilih selama 30 menit. Observasi dilakukan saat bersamaan dengan pengisian kuisioner skala Edinburgh. Setelah perlakuan diberikan sesuai waktu yang telah direncanakan maka di akhir program, hasil pengisian kuisioner akan dikelompokkan, dihitung, dan diskor untuk mengetahui perbedaan risiko. Resiko dikategorikan menjadi tiga derajat. Skor 1-9 menunjukan bahwa tidak ada tanda resiko depresi, 10-12 menunjukan bahwa resiko sedang depresi dan skor 13-30 menunjukan bahwa risiko berat timbulnya depresi nifas. Setelah itu, hasil tersebut dibandingkan antara derajat risiko depresi primipara dan multipara.

Hasil pengumpulan data ini kemudian akan diolah dengan menggunakan program komputer. Kemudian untuk menentukan apakah ada perbedaan antara primipara dan multipara terhadap risiko terjadinya depresi nifas, akan dilakukan analisa data dengan uji independent test. Variabel dalam penelitian ini antara lain adalah Variabel bebas (independent variabel) adalah skala pengkajian risiko depresi nifas ( skala Edinburgh). Variabel terikat (dependent variabel) adalah primipara dan multipara. Variabel pengganggu (confounding) adalah umur, riwayat depresi sebelumnya. 
Beberapa definisi operasional yang perlu dirumuskan dan berkaitan dengan penelitian ini adalah: (1) Skala pengkajian risiko depresi nifas adalah alat yang berbentuk skala yang berfungsi untuk mengidentifikasi risiko timbulnya depresi nifas; (2) Depresi nifas adalah munculnya gangguan mood dan kondisi emosional berkepanjangan yang mewarnai seluruh proses mental yang muncul setelah melahirkan (nifas) pada periode mulai hari keenam (1 minggu pertama) sampai kurang lebih 3-4 minggu; (3) Primipara adalah ibu nifas yang melahirkan pertama kali; (4) Multipara adalah ibu nifas yang melahirkan lebih dari satu kali.

Penelitian ini tidak melakukan pengujian terhadap instrumen yang akan digunakan. Hal ini dikarenakan instrumen yang digunakan sudah dilakukan validasi oleh beberapa peneliti sebelumnya dengan tingkat validasi yang berbeda-beda. Beck dan Gable (2001) menyebutkan bahwa validasi EPDS tercatat sebagai berikut sensitivity $=86 \%$, specificity $=78 \%$, positive predictive value $=73 \%$, dan coefficient alpha $=0.87$ dengan sampel 84 wanita nifas. Pengumpulan data melalui pemberian kuesioner dan pengukuran risiko depresi dengan menggunakan skala Edinburgh oleh peneliti di ruang rawat inap bersalin RSU X Medan pada Agustus-Oktober 2008.

\section{Hasil}

Pada tahap pelaksanaan telah dilakukan pengumpulan data dan telah terkumpul sebanyak 50 responden
(100\%) yang terdiri dari 25 ibu primipara dan $25 \mathrm{ibu}$ multipara. Pada setiap responden disurvei dengan menggunakan skala Edinburgh. Semua responden dapat menyelesaikan program tanpa ada responden yang drop-out. Kemudian dari data yang terkumpul telah dilakukan pengolahan dan analisa data dengan hasil sebagai berikut:

\section{Distribusi Ibu Nifas Primipara dan Multipara Menurut Usia}

Berdasarkan Tabel 1 didapatkan bahwa mayoritas ibu primipara dan multipara berada pada rentang usia 20-30 tahun. Hal ini dimungkinkan karena usia menikah mulai bergeser, yang sebelumnya atau beberapa dekade yang lalu mayoritas remaja putri menikah pada usia di bawah 20 tahun sekarang sudah bergeser di atas usia 20 tahun seiring dengan pemasyarakatan program keluarga berencana. Sementara itu pada rentang usia 3-40 tahun sebanyak $8(32 \%)$ ibu multipara masih melahirkan, hal ini dialami oleh beberapa ibu yang agak terlambat mempunyai anak atau ibu yang memiliki anak lebih dari 2 orang.

\section{Distribusi Risiko Depresi Nifas Primipara dan Multipara}

Berdasarkan hasil distribusi risiko depresi nifas untuk setiap skala dapat dijelaskan bahwa skala Edinburgh memiliki kemampuan mendeteksi pada keadaan tidak berisiko mengalami depresi nifas sebesar $20(80 \%)$

Tabel 1. Distribusi Usia Ibu Melahirkan Menurut Usia

\begin{tabular}{ccccc}
\hline & \multicolumn{3}{c}{ Status Obstetrik } & Multipara \\
\cline { 2 - 5 } Usia & n & Primipara & n & \% \\
\cline { 2 - 5 } & 9 & 36 & 2 & 8 \\
$20-30$ & 11 & 44 & 14 & 56 \\
$31-40$ & 5 & 20 & 8 & 32 \\
$>40$ & 0 & 0 & 1 & 4 \\
\hline
\end{tabular}

Tabel 2. Distribusi Risiko Depresi Nifas Primipara dan Multipara

\begin{tabular}{ccccccc}
\hline \multirow{2}{*}{$\begin{array}{c}\text { Status } \\
\text { Obstetrik }\end{array}$} & \multicolumn{4}{c}{ Resiko depresi } & \multicolumn{2}{c}{ Risiko tinggi } \\
\cline { 2 - 7 } & $\mathbf{N}$ & $\mathbf{\%}$ & $\mathbf{N}$ & $\mathbf{\%}$ & $\mathbf{N}$ & $\mathbf{\%}$ \\
\hline Primipara & 12 & 48 & 9 & 36 & 4 & 16 \\
Multipara & 20 & 80 & 3 & 12 & 2 & 8 \\
\hline
\end{tabular}


pada multipara. Sementara itu, pada rentang risiko sedang dan risiko tinggi depresi post partum, ditempati oleh ibu primipara sebesar $9(36 \%)$ dan $4(16 \%)$.

\section{Perbedaan Risiko Tingkat Depresi Nifas Primipara dan Multipara}

Analisis perbedaan tingkat kepekaan skala diuji menggunakan uji Independent t-test. Menurut Djarwanto (2001), menerangkan bahwa proses pengujian Independent t-test digunakan apabila kedua kelompok variabel bersifat independen dan berskala interval atau rasio dan hal ini sebagai dasar untuk menentukan kesimpulan terhadap hasil penelitian apakah Ho ditolak ataupun Ho diterima.

Berdasarkan Tabel 2 tentang distribusi risiko depresi nifas primipara dan multipara dan diperkuat dengan Tabel 3 yang berisi uji statistik Independent t-test menunjukkan bahwa ada perbedaan yang significan antara ibu primipara dan multipara terhadap risiko depresi nifas dengan menggunakan skala Edinburg dengan t-hitung $=3,74$ dan tingkat signifikansi $(\mathrm{p}=$ 0.000).

\section{Pembahasan}

Hasil penelitian menunjukkan bahwa ibu multipara memiliki jumlah lebih besar berada pada risiko rendah dibandingkan dengan ibu primipara. Hal ini dimungkinkan karena ibu multipara secara psikologis lebih siap menghadapi kelahiran bayi dibandingkan dengan ibu primipara. Ibu multipara sudah memiliki pengalaman menghadapi kelahiran anak sebelumnya sehingga secara nyata dapat diperlihatkan dari hasil pengukuran tersebut pada risiko sedang dan berat di tempati oleh ibu primipara. Hal ini dimungkinkan karena mayoritas ibu primipara mengalami stres ketika menghadapi kelahiran anak pertama.

Hasil penelitian ini sesuai dengan penelitian yang dilakukan oleh O'Hara dan Swain (1996) bahwa kejadian depresi nifas ini banyak dialami terutama oleh para wanita yang baru melahirkan pertama kali (primipara mother) yaitu $13 \%$ wanita melahirkan anak pertama mengalami depresi nifas pada periode tahun pertama nifas. Keadaan ini dapat juga diperburuk oleh situasi external misalnya konflik keluarga. Selain itu, faktor pengalaman menghadapi kelahiran dan faktor genetik juga sangat memegang peranan penting menentukan derajat risiko depresi nifas. Sementara itu, bahwa periode nifas (puerperium remote) yaitu waktu yang diperlukan untuk pulih dan sehat secara sempurna adalah cukup lama yaitu sekitar 6 minggu. Keadaan demikian juga mempengaruhi kondisi psikologis ibu nifas terutama primipara. Ibu primipira biasanya akan mengalami banyak kesulitan dalam proses adaptasi peran menjadi orang tua (bonding parenting).

Sebenarnya terdapat beberapa fase adaptasi peran parenting yaitu 1) Fase ketergantungan (taking-in), fase ini terjadi pada hari 1-3 nifas yang ditandai dengan kondisi ibu masih sangat membutuhkan perlindungan dan pelayanan karena ibu memfokuskan energinya pada bayinya yang baru lahir; 2) Fase yang kedua yaitu fase ketidaktergantungan (taking hold), fase ini terjadi hari ketiga dan berakhir sampai minggu keempat atau kelima. Selama fase ini sistem pendukung (support) menjadi sangat bernilai bagi ibu primipara yang membutuhkan sumber informasi dan pemulihan fisik (involusi) sehingga ia dapat beristirahat dengan baik.

Mekanisme pertahanan diri pasien merupakan sumber penting selama fase ini karena apabila tidak terpenuhi dapat menstimulasi timbulnya depresi nifas. 3) Fase saling ketergantungan (letting go), fase ini terjadi setelah minggu ke lima periode nifas dimana kondisi fisik maupun psikologis ibu sudah stabil, involusi berjalan baik dan adaptasi adekuat. Tetapi bila ibu nifas tidak dapat melewati fase ini dengan baik maka kemungkinan dapat mengarah pada keadaan nifas

Tabel 3. Perbedaan Risiko Tingkat Depresi Primipara dan Multipara

\begin{tabular}{lcccc}
\hline Status Obstetrik & N & M & t & p \\
\hline Primipara & 25 & 10.1 & & \\
Multipara & 25 & 7.5 & 3.74 & 0,000 \\
\hline
\end{tabular}


psikosis yang termasuk dalam gangguan mental. Namun demikian, hal ini tidak dilakukan dalam penelitian ini.

Bloch, et al., (2000) menunjukan bahwa faktor yang berpengaruh hanya penurunan hormon reproduksi setelah melahirkan, tetapi beberapa studi menunjukan beberapa faktor lain juga berpengaruh terhadap munculnya depresi nifas seperti stress, riwayat depresi nifas sebelumnya (tidak selalu timbul setelah nifas), dan adanya riwayat keluarga yang mengalami gangguan mood (O'Hara \& Swain, 1996). Namun demikian, faktor di bawah ini berdasarkan studi dari Wisner, et al., (2001), yang menjelaskan bahwa tidak ada hubungannya terhadap munculnya depersi nifas pada ibu post partum. Faktor tersebut diantaranya; level pendidikan, jenis kelamin dari bayi yang dilahirkan, apakah dia melakukan pemberian ASI (Air Susu Ibu) atau tidak, macam persalinan, dan apakah kehamilan direncanakan atau tidak. Sementara itu, sampai saat ini skala Edinburgh merupakan alat yang bisa diandalkan untuk mengetahui risiko depresi nifas.

Menurut Afiyanti (2002), bahwa melaporkan caracara deteksi dan pencegahan depresinifas. Salah satu uji tapis (screening tests) yang digunakan adalah dengan skala nifas Edinburgh sehingga dapat mendeteksi dan memonitor perkembangannya pada wanita-wanita yang mempunyai risiko mengalami depresi nifas. Adapun skala Beck menurut studi dari Heh dan Fu (2002) mempunyai angka validitas yang lebih rendah jika dibandingkan dengan skala Edinburgh karena skala Beck lebih tepat digunakan untuk pengkajian depresi secara umum. Hal ini dapat dijelaskan bahwa kepekaan skala bisa disebabkan karena perbedaan lokasi penelitian dan juga jumlah sampel.

\section{Kesimpulan}

Berdasarkan hasil penelitian ini dapat disimpulkan bahwa ada perbedaan yang bermakna terhadap depresi nifas pada ibu primipara dan multipara yang dirawat di ruang rawat inap bersalin RSU X Medan. Perhitungan persentase yang didapatkan adalah mayoritas risiko depresi nifas dialami oleh ibu dengan status primipara. Peneliti memberikan saran untuk menerapkan skala Edinburgh sebagai alat deteksi depresi nifas pada ibu primipara dan multipara mengingat beberapa hal diantaranya bahwa depresi nifas kadang terjadi tanpa diketahui dulu sebelumnya. Oleh karena itu, dengan menerapkan skala Edinburgh diharapkan dapat di lakukan deteksi dini terhadap risiko depresi nifas (AT, YR, TN).

\section{Referensi}

Afiyanti, Y. (2002). Deteksi dan pencegahan dini postpartum. Jurnal Keperawatan Indonesia, 6 (2), 70-76.

Armstrong, K.L., Fraser, J.A., Dadds, M.R., \& Morris, J. (2000). Promoting secure attachment, maternal mood and child health in a vulnerable population: A randomized controlled trial. J Paediatr Child Health, 36, 555-562.

Beck, C.T., \& Gable, R.K. (2001). Further validation of the postpartum depression screening scale. Nursing Research, 50 (3), 155-164.

Beck, J.S., Vartuli, J.C., Roth, W.J., Leonowicz, M.E., Kresge, C.T., Schmitt, K.D., Chu, C.T.W., Olson, D.H., \& Sheppard, E.W. (1992). A new family of mesoporous molecular sieves prepared with liquid crystal templates. J Am Chem Soc, 114 (27), 10834-10843. doi: 10.1021/ja00053a020.

Bloch, M., Schmidt, P.J., Danaceau, M., Murphy, J., Nieman, L., \& Rubinow, D.R. (2000). Effects of gonadal steroids in women with a history ofnifas depression. Am J Psychiatry, 157, 924-930.

Campbell, S.B., \& Cohn, J.F. (1991). Prevalence and correlates of postpartum depression in first-time mothers. Abnormal Psychology, 100, 594-599.

Cooper, P.J., \& Murray, L. (1998). Postnatal depression. BMJ, 316 (7148), 1884-1886.

Djarwanto, P.S. (2001). Mengenal beberapa uji statistik dalam penelitian (Edisi kedua). Yogyakarta: Liberty.

Heh, S., \& Fu, Y. (2002). Effectiveness of informational support in reducing the security of postnatal depression in Taiwan. Journal of Advanced Nursing, 42 (3), 30-36. 
Kustjens, S., \& Wolke, D. (2001). Effects of maternal depression on cognitive development of children over the first 7 years of life. Journal of Child Psychology and Psychiatry, 42, 623-636.

O’Hara, M.W., \& Swain, A.M. (1996). Rates and risk of postpartum depression: A meta-analysis. Int. Rev. Psychiatry, 8, 37-54.

Sharp, D., Hay, D.F., Pawlby, S., Schmücker, G., Allen, H., Kumar, R. (1995). The impact of postnatal depression on boys' intellectual development. $J$ Child Psychol Psychiatry, 36 (8), 1315-1336.
Tammentie, T., Tarkka, M.T., Astedt-Kurki, P., \& Paavilainen, E. (2002). Sociodemographic factors of families related to postnatal depressive symptoms of mothers. International journal of nursing practice, 8 (5), 240-246.

Wisner, K.L., Perel, J.M., Peindl, K.S., Hanusa, B.H., Findling, R.L., \& Rapport, D. (2001). Prevention of recurrent nifas depression: a randomized clinical trial. Journal Clinical Psychiatry, 62, 82-86. 